\title{
遭 \\ Die Arminianisme en gereformeerde prediking vandag
}

\author{
J.M. Vorster \\ Skool vir Kerkwetenskappe \\ Potchefstroomse Universiteit vir $\mathrm{CHO}$ \\ POTCHEFSTROOM \\ E-pos: dekjmv@puknet.puk.ac.za
}

\begin{abstract}
Arminianism and Reformed preaching today

A survey of sermons broadcast by the electronic media in South Africa has revealed that preaching in virtually all the major ecclesiastical traditions in this country is actually Arminian in character (Cilliers, 1996). This article focuses on the life and doctrines of Arminius (1559-1609) with special attention to his views regarding sin, the free will of man, God's grace and predestination. The influences of these doctrines of Arminius and his followers in the Netherlands, England, America and South Africa are also dealt with. In conclusion the article highlights the differences in doctrine between Arminianism and the Reformed tradition and the immense implications of Arminianism for Reformed preaching today.
\end{abstract}

\section{Inleiding}

In 1996 het daar in Suid-Afrika 'n interessante werk oor die prediking in SuidAfrikaanse kerke verskyn. Hierdie werk van Cilliers (1996:3) bespreek navorsingsresultate oor die leerstellige inhoud van vier-en-vyftig preke uit al die belangrike kerklike tradisies wat oor die elektroniese media gepreek is. Hy kom tot die konklusie dat negentig persent van die preke nie die evangelie van verlossing verkondig nie, maar wettisisties van aard is. Onder wettisistiese preke verstaan hy preke wat "... die sonde en dus die omvermoë van mense om die wêreld en hulleself te verander, nie ernstig (neem) nie" en preke "... wat die vermoë van die evangelie en dus die krag van God se genade nie emstig (neem) nie" (Cilliers, 1996:7, 8).

Later in die werk toon hy aan dat die leer van die totale verdorwenheid van die mens, soos uitgespel in Romeine 3:10-11 in die praktyk van dié prediking nie 
noodwendig funksioneer as 'n voorveronderstelling nie. As gevolg hiervan kom daar volgens hom 'n verstommende verskeidenheid trekke van volbloedPelagianisme en Arminianisme na vore (Cilliers, 1996:52). Afhangende van die dogmatiese vertrekpunt kan daar vrae oor die juistheid van Cilliers se gevolgtrekkings gevra word. Hierop word in hierdie artikel nie ingegaan nie. Wat wel duidelik is, is dat sy waarneming rym met wat Slaatte (1979:ii) reeds in 1979 in wyer verband opgemerk het toe hy gesê het: "Arminianism is a movement in theology that has far-reaching influence, especially since the days of the Evangelical Awakening, and should be overlooked no longer".

Arminianisme oefen steeds 'n groot invloed uit op die gereformeerde verlossingsleer (Bangs, 1971:17). Hierdie invloed reflekteer onvermydelik ook in die prediking. In hierdie artikel word gefokus op die Arminianisme en gereformeerde prediking vandag. Vanuit kerk- en dogmahistoriese perspektief word agtereenvolgens aandag gegee aan die lewe en leer van Arminius en sy invloed in Nederland, Engeland, Amerika en Suid-Afrika. By wyse van gevolgtrekkings word die implikasies van die Arminianisme vir hedendaagse gereformeerde prediking in Suid-Afrika aangetoon.

Die mees resente en omvattendste biografie oor Arminius is geskrywe deur C. Bangs. Vanuit sy Metodistiese tradisie het sy navorsing oor Arminius in 1942 begin en het hy ' $n$ verhandeling en proefskrif oor die onderwerp laat opvolg deur sy omvattende biografiese werk in 1971 (Bangs, 1971). Vir gegewens oor die lewe van Arminius word grootliks gesteun op die historiese materiaal van dié boek met verwysing na ander werke waar nodig. Waar die leer van Arminius behandel word, word die oorspronklike werk van Arminius self aan die orde gestel. Oor die invloed van die Arminianisme word primêre en standaard kerk- en dogmahistoriese bronne geraadpleeg.

\section{Die lewe van Arminius}

Bangs (1971:13) gee 'n goeie en akkurate chronologie van die lewe van Arminius teen die agtergrond van die belangrikste bakens van die geskiedenis van die Reformasie. Arminius is op 10 Oktober 1560 te Oudewater gebore as Jacob Harmensch. Hy het skoolgegaan in Utrecht by die Hieronimusskool en in sy opleiding is baie klem gelê op die Patristiek en die Skrif. In hierdie tyd van sy lewe is hy sterk beinvloed deur die geskrifte van Amesius en die piëtisme van die Broeders des Gemenen Levens. By hierdie skool het hy ook sy lewenslange vriend en vertroueling, Uitenbogaert, ontmoet. Na sy skoolopleiding het hy sy studie in Marburg voortgesit.

'n Traumatiese gebeurtenis in die lewe van Arminius het sy lewe ingrypend geraak en het waarskynlik sy denke oor die kerk wesenlik beinvloed. Hierdie gebeurtenis was die Spaanse aanslag op sy geboortedorp, Oudewater, op 19 
September 1575 - 'n aanslag waarin sy hele familie uitgewis is. Die wreedheid in die naam van godsdiens het by Arminius 'n soepelheid in denke oor kerk en teologie nagelaat en het daartoe gelei dat hy hom deur sy lewe heen verset het teen starre, rigiede en fanatiese denke wat so eie aan die godsdiensonverdraagsaamheid van sy tyd was. Ook in die latere stryd wat rondom sy beskouinge gevoer is, het hy hom beywer vir genuanseerdheid en verdraagsaamheid.

$\mathrm{Na}$ sy skoolopleiding het hy aan Leiden gestudeer waar hy veral deur twee leermeesters beïndruk was. Die een was Coolhaes wie se piêtistiese oortuiginge in 1581 deur die Sinode van Middelburg verwerp is. Die ander een was Ramus wat logika gedoseer het en wie se teorieë die denkpatroon van Arminius wesenlik beïnvloed het. Veral Ramus se liefde vir dichotomisering in sy analitiese denke het neerslag gevind in Arminius se poging tot 'n logiese uiteensetting van leerstellige kwessies (Bangs, 1971:59). So het hy byvoorbeeld die leer oor die predestinasie benader met die beginsels van die logika wat deur Ramus uitgewerk is.

'n Baie belangrike fase in sy lewe was die tydperk wat hy onder Beza, die opvolger van Calvyn, in Genevè gestudeer het. Hierdie studie het geduur van 1582 tot 1586 met 'n kort onderbreking vir studie in Basel in 1583-1584 (Walker, 1992:539). Anders as Calvyn se soepel benadering in die omskrywing van die predestinasie het Beza die kwessie uitgewerk tot 'n leerstuk met terme soos infraen supralapsarisme. Hy het self gekies vir die supralapsariese standpunt waarin hy die uitverkiesing apriories gestel het in die benadering van die verlossingsleer (vgl. Letham, 1988:45). Waar Calvyn die predestinasie beskryf het as 'n gegewe uit die Godsopenbaring, het Beza daarvan 'n fundamentele leerstuk gemaak. Hierdie benadering het dan ook in Calvinistiese kringe heel gou die benaming gekry van hoè Calvinisme. Vanuit die beginsels van die logika, soos deur Ramus geleer, het Arminius vroeg in sy studie in Genevé reeds met die standpunt van Beza in botsing gekom. In 1586 het Arminius 'n besoek gebring aan Italië waar hy in kontak gekom het met die Jesuiète. In sy latere lewe is hierdie besoek teen hom gehou met die argument dat die gesprek met die Jesuiëte sy denke oor predestinasie beïnvloed het.

Die volgende fase in sy lewe was sy bedieningsloopbaan in die gemeente van Amsterdam vanaf 1588 tot 1603 (Bangs, 1971:83). In Amsterdam het daar in daardie jare ' $n$ vryheidsgees geleef - in teenstelling met die fanatiese godsdiensstryd in Europa. Onder die inwoners was daar reaksie teen die vervolging van die Anabaptiste deur die Protestante en teen die rigiede en wrede optrede van die Roomse Inkwisisie. Die gereformeerdes in Amsterdam is in die tyd deur die gereformeerdes van Antwerpen vermaan oor vermeende laksheid in leerstellige suiwerheid. Op 5 Oktober 1587 het Arminius by die klassis aangemeld vir beroepbaarstelling. Die sitting van die klassis het net bestaan uit predikante. Sedert die Sinode van Dordrecht 1578 en die Sinode van Middelburg 1581 was 
die Nederlandse Geloofsbelydenis in gebruik as die dokument wat predikante as ondertekeningsformulier moes onderteken. Daar kan egter nie vasgestel word of Arminius die dokument onderteken het nie. Saam met vyf ander predikante het hy die gemeente van Amsterdam vir vyftien jaar bedien en $45 \%$ van sy werke in hierdie periode geskryf, hoewel niks toe gepubliseer is nie. Sy werke is trouens nie oorwegend in Nederlands gepubliseer nie, maar merendeels in Engels, veral in die laat sewentiende eeu.

Gedurende 1591 het Arminius begin preek uit Romeine 7 en het hy beweer dat hierdie gedeelte van die brief handel oor die onwedergebore mens. Hy is toe deur sy medeleraar Plancius daarvan beskuldig dat hy die erfsonde misken en sodoende in die vaarwaters is van die Pelagianisme, semi-Pelagianisme en Socinianisme en dat hy in stryd is met die Nederlandse Geloofsbelydenis en die Heidelbergse Kategismus. Arminius self het dit ontken en beweer dat sy interpretasie in ooreenstemming is met al die gereformeerde konfessies van sy tyd. Sy preke uit Romeine 9 gedurende 1593 het weer kritiek van die kerkraad ontlok, maar vanweë gebrek aan bewyse en die verduideliking van Arminius is die klagtes laat vaar. Hy is daarna nooit weer deur die kerkraad tot verantwoording geroep nie. Benewens sy konsentrasie op die prediking uit Romeine 7 en 9 het hy hom ook veral toegespits op Maleagi, Markus, Johannes, Galasiërs en Openbaring 2 en 3 (Bangs, 1971:140).

Uit sy pastorale werk en optrede by meerdere vergaderings blyk dit dat Arminius ten opsigte van die leer van ander tradisies - soos dié van die Anabaptiste oor doop en kerkregering - gereformeerde standpunte ingeneem het. Tog blyk dit dat hy huiwerig was om standpunt in te neem teen die Anabaptisme oor die leer van die erfsonde, genade en die vrye wil van die mens. Tydens die plaag van 1601 is hy aangegryp deur die sterwendes se gebrek aan sekerheid en dit het ook sy denke oor die verlossing beïnvloed soos later sal blyk.

Vanaf 1603 tot 1609 met sy dood was Arminius professor in Leiden en hier het die stryd in die kerke in Nederland oor sy leer in felheid toegeneem. Op 7 Februarie 1604 het hy begin met sy bekende redes teen Gomarus. Hy het nie die Calvinisme as sodanig aangeval nie maar, volgens hom, probeer om die verlossingsleer van Calvyn en sy navolgers so te interpreteer dat God nie beskou kan word as die outeur van die sonde nie. Rondom hierdie uitgangspunt het Arminius sy beskouinge oor sonde en genade geweef. Verskeie verweergeskrifte uit sy pen het die lig gesien en dit het gekulmineer in sy verklaring voor die State-generaal op 30 Oktober 1609. Uit al hierdie geskrifte kan nie 'n sistematiese teologie afgelei word nie maar kan sy "herinterpretasie" van die Calvinisme duidelik waargeneem word. Aan die belangrikste aspekte hiervan word vervolgens aandag gegee. 


\section{Die leer van Arminius}

\subsection{Die sonde}

Die uitstaande vertrekpunt in die teologie van Arminius was dat hy sy verlossingsleer so wou formuleer dat God nie gesien kan word as die outeur van die sonde nie. Hy het Beza juis verkwalik dat sy supralapsariese beskouing van die leer van die predestinasie onvermydelik lei tot die standpunt dat God die outeur is van die sonde. Daarom het hy ook voorgestel dat die Nederlandse Geloofsbelydenis en die Heidelbergse Kategismus op dié punte so gewysig word dat die moontlikheid heeltemal uitgeskakel word (Arminius, 1956c:266).

Oor die erfsonde het Arminius (1956b:317) gesê dat die sonde van Adam nie beskou kan word as oordraagbaar op die hele mensdom in die volle sin van die woord nie. Die mens se sonde is nie korporatief nie, maar individueel. Oor die teenwoordigheid van die sonde in die individu moet volgens hom onderskei word tussen die inwoning (inhabitans) van die sonde en die bestaan in sonde (inexistens). By inhabitans regeer hierdie sonde en dit is die mens wat in Romeine 7 beskryf word, dit wil sê, die onwedergebore mens. Sonde in gelowiges is inexistens; die sonde is teenwoordig, maar nie as ' $\mathrm{n}$ regerende mag nie (Bangs, 1971:189; Shedd, 1978:178). Die konsekwensie van die standpunt van Arminius is dat hy die effek van die erfsonde as die "totaal dood wees in die sonde" van die hele menslike geslag versag het en dat dit implikasies het vir sy beskouing oor die vrye wil van die mens. Met sy sagter beklemtoning van die erfsonde het hy reeds afgewyk van die standpunt van Calvyn soos hy dit in die 1559-uitgawe van die Institusie verwoord het (Calvyn, 1949a:239).

\subsection{Die vrye wil van die mens}

Oor die vrye wil van die mens het Arminius (1956a:252) in opvolging van die Reformatore uit die Calvinistiese tradisie gestel dat die mens as volmaakte skepsel met die hulp van God se genade 'n vrye wil gehad het. Met die sondeval is hierdie vrye wil egter vernietig. Die gevalle mens moet wedergebore word. Hiervandaan volg hy dan ' $n$ ander argument as Calvyn. Hy stel dat, hoewel die vrye wil verlore gegaan het met die sonde, God wel 'n algemene of genoegsame genade gee aan alle mense wat die wil bevrug tot die goeie (Arminius, 1956c:472). Bangs (1971:216) vat sy standpunt soos volg saam: "Thus Arminius says that 'grace is present with all men, by which their free will may be actually bent to good; but that there is in all men such a will as is flexible to either side upon acsession of grace"" (vgl. ook Berkhof, 1991:221, Cairns, 1981:325 en Jonker, 1994:127).

Die genoegsame genade van God buig die sondaar se wil sodanig dat dit vir hom moontlik word om te glo. Die mens kan weliswaar nie self bydra tot sy verlossing 
nie, maar hy kan kies vir of teen die verlossing in Christus. Hy kan die genade van God weerstaan en verkeerd kies. Die mens kan later ook uitval uit die genade. Hoewel die mens se wil deur die sonde vernietig is, gee die genoegsame genade van God wat aan alle mense gegee word aan die sondaar tog die besef dat hy Christus nodig het. Waartoe daardie besef hom bring, is sy eie verantwoordelikheid.

\subsection{God se genade}

Hulle wat deur die genoegsame genade tot die geloof kom, ontvang dan die effektiewe genade wat tot bekering en geloof lei. Arminius (1956a:253) definieer God se genade as God se toegeneentheid teenoor die sondaar. Hierdie affektiewe genade trek saam in Christus en op grond hiervan moet die leer van die predestinasie uitgewerk word. Die genade beteken ook dat die sondaar in Christus verlos word en dat die gawes van die Gees wat betrekking het op die vernuwing van die mens, in die mens "ingegiet" word. Deur hierdie genade ontvang die mens die voortdurende bystand van die Gees en daarsonder is geen goeie werke moontlik nie.

Die genade van God is egter nie onweerstaanbaar nie. Arminius (1956b:282) sê dat die Skrif leer dat baie mense die genade van die Gees weerstaan en die genade wat aangebied word, verwerp. Mense kan dus uitval uit die geloof en dus ook uit die redding.

Op die tema het hy uitgebrei in sy polemiek met Perkins en die sogenaamde "hoë Calvinisme" wat deur Beza aan die orde gestel is (Arminius, 1956f:197). Teenoor Perkins se onderskeiding van algemene en besondere genade het Arminius hom beroep op Augustinus en Aquinas en gepraat van een algemene of genoegsame genade wat aan almal aangebied word maar wat net effektief is vir dié wat glo. Hierin het hy egter van Calvyn en Beza verskil (Arminius, 1956f: 392). Bangs (1971:212) beweer dat Arminius met hierdie standpunt wel in beginsel aansluit by Calvyn. Sy bewering is egter foutief. Calvyn (1949b:17, 50, 71) praat wel oor die aanbod van die genade. Tog onderskei hy duidelik tussen 'n algemene roeping wat beteken dat die evangelie na almal uitgaan en 'n besondere roeping wat inhou dat dié wat deur die Here uitverkies is, onder inwendige verligting van die Gees gelei word om die evangelie aan te neem (Calvyn, 1949b:529). Op hierdie kardinale punt in die verlossingsleer is daar 'n duidelike verskil tussen Arminius en Calvyn. By Calvyn is die aanvaarding van die aanbod nie van die inens afhanklik nie maar is dit ' $n$ gawe van die Heilige Gees. Ook die latere Calvinisme het gesê dat die versoening in Christus genoegsaam (sufficiens) is vir alle mense, maar dat dit effektief (efficiens) is net vir dié wat glo.

Binne bogenoemde raamwerk het Arminius (1956b:316) ook die offer van Christus verduidelik. Die offer van Christus is in ooreenstemming met die 
Mosaïese wet en is 'n voorwaarde vir skuldvergiffenis. Die offer draai die gesindheid van God vanaf 'n gesindheid van oordeel en straf na 'n gesindheid van toegeneentheid (Shedd, 1978:370). Christus sterf vir almal, maar die redding kom alleen deur die geloof. Hieruit kom hy tot die gevolgtrekking dat mense wat verlore gaan, op eie verantwoordelikheid verlore gaan en nie volgens 'n dekreet van God nie (Amminius, 1986a:503). Hy verwerp dus die gedagte van verwerping soos Calvyn (1949a:470) dit gestel het, naamlik dat God sommige tot die geloof en ander tot die verderf voorbeskik het. So 'n dekreet bots volgens Arminius met die genade van God wat aan alle mense aangebied word. Hierdie standpunte oor sonde, genade en die vrye wil van die mens vorm die fondament van sy beskouing oor die predestinasie wat uiteindelik soveel teenkanting in Calvinistiese kringe uitgelok het.

\subsection{Predestinasie}

Vir Arminius (1956c:101) is die predestinasie die fondament van die Christendom en die verlossing. Hy vat sy beskouing hieroor soos volg saam:

This decree has its foundation in the foreknowledge of God, by which he knew from all eternity those individuals who would through his preventing grace, believe, and, through his subsequent grace would persevere, according to the before described administration of those means which are suitable and proper for conversion and faith, and, by which foreknowledge, he likewise knew those who would not believe and persevere (Arminius, 1956a:248; vgl. ook Arminius, 1956d:102; 1956e:453; 1956f: 295; 1986b: 560 en 1960:278).

Die verkiesing geskied langs die lyn van die volgende dekrete: eerstens vind die verkiesing van Christus plaas en hierdie verkiesing is die basis van die predestinasie (Arminius, 1956c: 100). Hy sê hieroor:

Het eerste precijs ende absoluut decreet Gods, om den sondighen mensche saligh te maecken is, dat hy besloten heeft zijnen sone Jesum Christum te stellen tot eenen Middelaer, Verlosser, Priester ende Coninc die de sonde deur zijnen doot te niete doe, de verloren salicheyt door zijne ghehoorsaemheydt verwerve ende deur zijne cracht mededeelde (Arminius, 1960:278).

Naas die verkiesing van Christus is daar die verkiesing van die gelowiges. Hulle word in Christus verkies en hulle is diegene wat hulle skuld bely, glo en hulle saligheid in Christus soek (vgl. Letham, 1988:45). Berou is die belangrike eienskap van die uitverkorene. Derdens is daar God se voorafbestemde aanduiding van die wyse van die verkiesing deur sy wysheid en geregtigheid en vierdens die verkiesing van die individue op grond van die voorkennis van God. 
Verkiesing van die individu rus dus in die voorkennis van God. God het vooruit gesien wie berou sal hê en glo en hy het hulle tot sy kinders en tot die ewige lewe uitverkies. Hulle ontvang skuldvergiffenis en die inwoning van die Gees kragtens die genadige beskikking van God. Ander gaan op eie verantwoordelikheid verlore. Onderliggend aan hierdie beskouing lê dus die uitgangspunt dat die mens die eerste tree moet gee in die verlossingsproses. Kragtens sy vrye wil wat deur die genoegsame genade van God omgebuig is, moet die mens eers vir Christus kies voordat die verlossing sy verloop kan neem. God en mens werk sinergisties saam in die verlossing.

Die bedoeling van Arminius was om te ontkom aan die supralapsarisme van Beza en die sub- of infralapsarisme van die Roomse semi-Pelagianisme. Sy beskouing het hom egter in botsing gebring met artikel 16 van die Nederlandse Geloofsbelydenis (NGB, 1992:488) wat in daardie tyd as die belangrikste gereformeerde belydenis beskou is. Artikel 16 van die Nederlandse Geloofsbelydenis dui aan dat God se barmhartigheid na vore kom in die feit dat Hy dié wat Hy verkies het, uit die verderf trek en hulle verlos: sy regverdigheid lê daarin dat $\mathrm{Hy}$ die ander in die verderf laat bly waarin hulle hulleself gewerp het. Die kern van Arminius se beswaar hierteen was dat so 'n beskouing God die outeur maak van die sonde (Hoenderdaal, 1975:138).

Hoewel voorstanders van die Arminianisme soos Bangs (1971:262 en 310) volhou dat Arminius hom nie verset het teen Calvyn nie, maar teen die "hoë Calvinisme" van Beza en Perkins, is sy leer oor die predestinasie in stryd met die beskouing van Calvyn, artikel 16 van die Nederlandse Geloofsbelydenis en Sondag 4 en 7 van die Heidelbergse Kategismus (1992:519 en 522). Calvyn (1949b:490) het in sy behandeling van Thomas Aquinas se siening van predestinasie op grond van God se "vooruitweet" van die meriete van die mens, die gedagte duidelik afgewys omdat hierdie beskouing die predestinasie tot die heerlikheid die oorsaak maak van die predestinasie tot die genade terwyl dit andersom moet wees. Op sy teenspraak ten opsigte van die uiteensetting van die ewige verkiesing in artikel 16 van die Nederlandse Geloofsbelydenis is reeds gewys. Wat in die artikel van die Nederlandse Geloofsbelydenis bely word, word ook gestel in Sondag 4 en 7 van die Heidelbergse Kategismus. God se regverdigheid wat in hierdie belydenisskrifte duidelik uitgespel word, is in duidelike teenspraak met die leer van Arminius.

Hoewel Arminius dit self nie so gesien het nie en dogmahistorici soos Bangs (1971:310) en Walker (1992:340) hom hierin gelyk gee, is sy beskouing, soos reeds aangedui is, sinergisties en daarom 'n afwyking van Calvyn en Augustinus (Aland, 1986:36). Sy beskouing is eerder in ooreenstemming met die sinergisme wat deurlopend na vore gekom het in die Pelagianisme, Semi-Pelagianisme, die Skolastiek en die Humanisme van Erasmus (Van Genderen, 1996:96). In sy 
poging om God nie te sien as die outeur van die sonde nie, het hy die mens die outeur van die verlossing gemaak.

\section{Die invloed van Arminius}

Die beskouing van Arminius oor predestinasie en verlossing het na sy tyd wêreldwyd inslag gevind. Hierdie invloed het veral vergestalting gevind in die stroming van subjektiwisme wat sekere prominente teologiese strominge in die sewentiende eeu tot vandag in die moderne Pinksterbewegings kenmerk (Bogaards, 1997:336). Onder subjektiwisme in hierdie verband word verstaan 'n verlossingsbeskouing waarin die mens gesien word as die vennoot van Christus in die verwerwing van die heil. Vir die doeleindes van hierdie artikel word toegespits op die invloed van die Arminianisme in Nederland, Engeland, Amerika en Suid-Afrika.

\subsection{Nederland}

In Nederland is Arminius in bepaalde kringe in die Nederlandse Hervormde Kerk hoog aangeslaan en nagevolg. Sy leer het egter ook fel kritiek ontlok, veral van die sogenaamde hoẻ Calviniste. Tydens sy bedieningsloopbaan in Amsterdam (1588-1603) was sy groot teenstander sy kollega in die bediening, Plancius, en tydens sy loopbaan as professor is hy fel deur sy mede-professor, Gomarus, teengestaan. Uit sy geskrifte blyk dit dat hy ook diskussies met ander teoloe gevoer het - ook buite Nederland.

Sy groot navolgers was die Remonstrante (Anon, 1988:268-269) wat in hulle strydgeskrif hulle verset het teen die hoé Calvinisme van Beza soos dit ook verwoord is deur Gomarus. Hulle standpunte het hulle in vyf punte gestel:

- God verlos in en deur Christus dié wat sal glo. Hiermee saam het hulle ook die verwerping erken.

- Christus sterf vir alle mense en deur die geloof kry mense deel aan die verlossing in Christus.

- Die mens het geen reddende genade in homself nie.

- Alle goeie werke van die mens rus in genade maar die genade en die werking van die Gees is weerstaanbaar.

- In Christus is dit vir die gelowige moontlik om te stry. Die Remonstrante wou - anders as Arminius self - hulle op daardie stadium nie uitspreek oor die vraag of die gelowige weer uit die genade kan uitval nie en het gevra dat die saak weer in die lig van die Skrif beoordeel moet word. 
Schulze (1988:200) is van oordeel dat die Remonstrante wel in artikel 5 gesê het dat die mens uit die genade kan uitval. Die volledige weergawe van die Remonstransie stel dit egter nie pertinent nie.

Op die oog af blyk die Remonstransie in ooreenstemming te wees met die verlossingsleer en die leer oor die predestinasie van die Reformasie. Hulle wou ook nie breek met die Calvinistiese opvatting nie. Tog toon stellings 1 en 2 afwykings van die Calvinistiese leer. Stelling 1 kies as uitgangspunt die verlossing op grond van die vooruitgesiene geloof en stelling 2 word nie gekwalifiseer nie Stelling 3 veronderstel die algehele verdorwenheid van die mens maar is wesenlik in stryd met die geloof as meriete van stelling 1. Anders as Arminius wou die Remonstrante nie sonder meer sê dat die mens weer kan uitval uit die genade nie en het verdere studie oor dié saak bepleit.

Die leer van Arminius en die beroering wat deur die Remonstransie veroorsaak is, het gelei tot die bekende Nasionale Sinode van Dordrecht (1618-1619) (Cairns, 1982:325). Van oor die hele gereformeerde wêreld van destyds is afgevaardigdes gestuur om die saak te besleg. Agt-en-twintig van die een-honderd-en-dertig afgevaardigdes was Calviniste van Engeland, Bremen, Hesse, die Palsgraafskap, Switserland en Frankryk (Nationale Synode te Dordrecht, 1620:7).

Na diepgaande insette van die groepe gedeputeerdes uit die verskillende streke in Nederland, die kerke uit die buiteland en die korps van professore aan die Universiteit van Leiden is die Dordtse Leerreëls opgestel en deur die Sinode as belydenisskrif aanvaar. In die belydenis word intensief gehandel oor die goddelike uitverkiesing en verwerping; die dood van Christus en die verlossing van die mense deur sy dood; die verdorwenheid van die mens, sy bekering tot God en die wyse waarop dit plaasvind en die volharding van die heiliges (Die Dordtse Leerreëls, 1992:557). Die uitverkiesing op grond van die vooruitgesiene geloof is met die volgende stelling duidelik afgewys:

Hierdie uitverkiesing het nie op grond van die voonuitgesiene geloof, gehoorsaamheid, heiligheid of enige ander goeie hoedanigheid of geskiktheid van die mens tot stand gekom nie. Dit alles kan nooit vooraf as rede of voorwaarde vir die uitverkiesing van die mens beskou word nie (Die Dordtse Leerreëls, 1992:559).

Die totale verdorwenheid van die mens en die sekerheid van die heil is ook sterk beklemtoon. Die grondlyne van die Arminiaanse verlossingsleer is dus pertinent afgewys. Hiermee saam het die sinode egter nie 'n supralapsariese beskouing, soos dit by Beza na vore gekom het en waarteen Arminius hom verset het, verdedig nie. Die verantwoordelikheid van die mens tot heilstoeëiening word in hoofstuk 1 artikel 4 gestel: 
Die toorn van God bly op hulle wat hierdie evangelie nie glo nie. Hulle wat die evangelie egter aanneem en die Verlosser, Jesus, met 'n ware en lewende geloof omhels, word deur Hom van die toorn van God en van die verderf verlos, en Hy skenk hulle die ewige lewe (Joh. 3:36; Mark. 16:16) (Die Dordtse Leerreëls, 1992:557).

Die Dordtse Leerreëls het in die gereformeerde kerklike wêreld wye steun maar ook teenkanting ontlok. Sowel die Lambeth Artikels as die Westminster Konfessie het oor die uitverkiesing die weg opgegaan van dié konfessie (Walker, 1992:548; Bettenson, 1988:245). Die invloed van die Arminianisme in Europa het egter nie uitgebly nie (Harnack, 1897:686, Jonker, 1994:132). Vroeëre briewe van Arminius en Uitebogaert na Parys het in kerklike kringe 'n pro-Arminiaanse klimaat geskep wat gelei het tot reaksie teen die sinode van Ale's wat die Dordtse Leerreëls in 1620 aanvaar het. Die grootste invloed van die Arminianisme ná die Sinode van Dordrecht was egter in Engeland.

\subsection{Engeland}

Die eerste invloed van die Arminianisme in Engeland het meer gegaan oor sy beskouing dat die staat gesag moet hê oor die kerk (Hoenderdaal, 1975:143). Vir sy leer oor die predestinasie het daar egter ook al 'n vrugbare teelaarde bestaan. In die Engelse Reformatoriese tradisie het verset opgebou teen Perkins se supralapsariese standpunte. Die Calviniste het gepoog om Perkins se beskouing via die reeds genoemde Lambeth Artikels in te skryf in die "Thirty-nine Articles". Hierin het hulle egter nie geslaag nie.

Die terrein vir die verdere invloed van die Arminianisme is verder voorberei deur Andrewes, Overall en Cosin (Hoenderdaal, 1975:152). Ten spyte van die Dordtse Sinode se duidelike uitspraak teen die Remonstransie was daar ook afgevaardigdes uit Engeland wat tot die Arminianisme oorgehaal is, onder andere Ward en Goad. Hales het openlik gesê dat hy afskeid geneem het van die Calvinisme (Dewar, 1974:108). Ander wegbereiders vir die Arminianisme was die Kwakers met hulle universalisme, die Unitariêrs en die vтoeë Baptiste (Nuttall, 1962:48). Nederlandse werkers wat op daardie stadium moerasse in Engeland drooggelê het, was ook Arminiaans en het die invloed in Engeland aangehelp.

Die groot verbreiding van die Arminianisme het egter 'n eeu na die Dordtse Sinode gekom met die Revival onder leiding van Wesley en die invloed van die Metodisme (Letham, 1988:46; Walker, 1992:596; Cunningham, 1969:509). Dit is interessant om daarop te let dat Wesley 'n blad begin uitgee het met die titel Arminian Magazine. In die eerste nommer is 'n artikel aan Arminius gewy (Bogaards, 1997:23). Anders as die Nederlanders het die Wesleyane moeite 
gedoen om die werke van Arminius te bundel en te versprei. Sy werke is tot vandag toe meer geredelik in Engels as in Nederlands beskikbaar.

Die Arminiaanse invloede blyk veral uit die Wesleyaanse konfessies. In Leith (1982:353) se versameling van Christelike konfessies is twee belangrike dokumente van die Metodisme vervat. Die een is die "Twenty-five articles of Religion" wat 'n hersiening was van die "Thirty-nine Articles" van die Church of England. Die hersiening is deur Wesley self gedoen. In 1784 is hierdie dokument amptelik gekondoneer deur die Methodist Conference of Baltimore.

In die dokument word onder andere die volgende sake aan die orde gestel: Artikel 7 erken die erfsonde en dit is daarom onregverdig om die Metodisme sonder meer van 'n Pelagiaanse sondeleer te beskuldig. Artikel 8 meld egter dat die mens se wil deur die genade van God omgebuig word sodat sy wil vry word om 'n keusemoontlikheid uit te oefen. Hierin word aangesluit by Arminius se leer oor die genoegsame genade. Die mens se positiewe keuse vir Christus word 'n voorwaarde vir verlossing. Die heil word dus nie uit vrye genade toegesê nie maar wel aangebied. Dit hang van die mens af of hy dit wil aanneem of nie. Hieruit vloei logies voort wat in artikel 12 gestel word, naamlik dat die mens kan uitval uit die genade en dat die genade nie onweerstaanbaar is nie (vgl. ook die beoordeling van Bolster, 1952:153 en Berkhof, 1991:222).

Die ander belangrike dokument is getitel "The Scriptural way of salvation" wat in 1765 die lig gesien het. Hierin sê Wesley (1982:360) dat die verlossing uit genade gegee word aan alle mense maar dat dit effektief word vir die mense wat God aanneem. Die heiliging vind dan ook momenteel plaas. Regverdiging geskied deur die geloof, maar dit word aan alle mense aangebied. Deur sy vrye wil kan die mens Christus aanneem of verwerp. Dit was dan ook hierdie universalistiese beskouing wat gelei het tot Wesley se bekende uitspraak: "The world is my parish" (Nuttall, 1962:59). Basiese Arminiaanse beskouings is dus deur Wesley bevorder - beskouings soos die vrye wil van die mens, die universele aanbod van die genade, die predestinasie op grond van vooruitgesiene geloof en momentele heiliging. Hierdie beskouings het die kerklike lewe in Engeland daarna ingrypend beïnvloed.

\subsection{Amerika}

In Amerika is die Arminianisme veral deur die Anglikanisme bevorder (Walker, 1992:572). Dieselfde gedagtes wat hieroor in hierdie kringe in Engeland geleef het, is in die laat-sewentiende eeu oorgedra na Amerika. Ook 'n gedeelte van die Puriteine het hiertoe bygedra. Hulle was die eerste pioniers wat sending onder die inheemse bevolking gedoen het en in die uitvoering van die sendingopdrag het Arminiaanse leerstellinge na vore gekom. Dit het gelei tot 'n skeuring in hulle 
midde en die Arminiaanse deel het die binding aan die Westminsterkonfessie tersyde gestel (McColloh, 1962:69).

'n Belangrike stimulus vir die leer van Arminius was die boek van Python oor die verlossing waarin hy direk aangesluit het by Grotius wat 'n leerling was van Arminius te Leiden. Die Arminiaanse vryheidsgedagte het die pioniers ook getref en dié gees is versterk deur die Skotse, Ierse en Nederlandse Arminiaanse immigrante asook die Unitariërs (McColloh, 1962:70). Soos in Engeland het die grootste invloed egter gekom van die Metodiste. McColloh (1962:73) beskryf die invloed soos volg:

The doctrine preached by the Methodist circuit riders was also well adapted to meet the hearty acceptance of the frontiersman. It was a gospel of free will and free grace, as opposed to the doctrines of limited grace, and predestination preached by the Calvinistic Presbyterians, or even the milder Calvinism of the Baptists. The frontier Methodist preachers brought home to the pioneers the fact that they were masters of their own destiny, an emphasis which fitted in exactly with the new democracy rising in the West, for both emphasized the actual equality of men.

In die agtiende en negentiende eeue is die Arminiaanse verlossingsleer in Amerika aktief uitgedra deur The Methodist Quarterly Review. Dié gees is in die twintigste eeu versterk deur sekere Presbiteriaanse groepe, die Baptiste, Mennoniete, Unitarièrs en Pentakostaliste. In sy samevatting oor die kernaspekte van die Christendom in Amerika kom McColloh (1962:80) tot die gevolgtrekking dat die leer van Arminius in dié wêrelddeel groter inslag gevind het as die leer van Calvyn, Beza of Junius. Vanweë die toenemende invloed van die Amerikaanse Christendom oor die wêreld, het hierdie denke hiervandaan oor die hele wêreld versprei.

\subsection{Suid-Afrika}

Die eerste koloniste aan die Kaap het in 1852 die leer van die Sinode van Dordrecht in Suid-Afrika gevestig. Hierdie leerstellinge is versterk met die koms van die Franse Hugenote in 1688 (Hofmeyr, 1994:11). In hierdie stadium het die Arminianisme nie veel inslag gevind nie.

Soos in Engeland en Amerika is die Arminianisme deur die Anglikanisme en veral die latere Metodisme in Suid-Afrika ingedra. Met die kort Britse besetting van die Kaap in 1795 tot 1803 het die bevolking aan die Kaap in kontak gekom met die Arminiaanse vorm van Anglikanisme (Hincliff, 1968:13). Nadat die Kaap in 1815 'n Britse kolonie geword het, het hierdie invloed op verskeie maniere nog verder uitgebrei. In die eerste plek het die Church of England in South Africa deur die koms van soldate en immigrante gegroei en vanwee sy invloed op die sendingveld die Arminiaanse idees uit Engeland na Suid-Afrika oorgedra. Soos in 
Amerika het die Arminiaanse gees 'n strewe gewek vir die erkenning van vryheid en burgerlike regte (vgl. Donaldson, 1994:52). Verder het die Britse owerheid die Kaapse Nederduitse Gereformeerde Kerk gedwing om gebruik te maak van Skotse predikante in plaas van predikante uit Nederland (Krüger, 1957:44). Onder hierdie predikante was die bekende en invloedryke Andrew Murray wie se Arminiaanse sentimente duidelik blyk uit sy volgende uitsprake: "juiste de adel en de heerlikheid van de mensch (is), dat hij niet gelijk de dier, door het blinde instinkt wordt gedreven, maar het vermogen besit van door vrije keuse, het goede te willen en te doen ..." (Murray, 1868:289).

Volgens Krüger (1957:52) het Murray ook geleer dat die mens die genade van God kan weerstaan. Oor die leer van die predestinasie het hy ook afgewyk van die Calvinistiese opvatting en sy sentimente met Arminius en die Wesleyanisme getoon (Coetzee, 1986:31). Ander Skotse predikante het sy sentimente gedeel en op hierdie wyse het Arminiaanse gedagtes ook die Nederduitse Gereformeerde Kerk binnegedring.

Die groot invloed van die Arminianisme het egter hier te lande gekom van die Metodisme. In die vroeg agtiende eeu het die stroming veral deur middel van die Britse soldate in Suid-Afrika posgevat (Donaldson, 1994:60). Daama het dit gegroei soos in Engeland en Amerika. Die Metodiste het 'n besondere sendingywer openbaar wat meegebring het dat die Metodiste Kerk vinnig onder die inheemse bevolking gegroei het en die Arminiaanse verlossingsleer deur middel van die volgelinge van Wesley hier gevestig is.

Benewens hierdie strominge het die koms van die Pentakostalisme en die Charismatiese Beweging in die twintigste eeu tot die verdere versterking van die Arminiaanse verlossingsleer bygedra. Hierdie bewegings het ten opsigte van die predestinasie en die vrye wil van die mens nog verder as Arminius gegaan in die rigting van volbloed-Pelagianisme (Smith, 1992:46 en 52). Die bekering in die sin van wedergeboorte word beskou as voorwaarde van verlossing en die verwerwing van geloof en die Heilige Gees as toegif op die positiewe vrye keuse van die mens teen die agtergrond van die universele aanbod van God se genade.

Bogenoemde kort oorsig van die invloed van die Arminianisme in Suid-Afrika verklaar gedeeltelik die bevindings van Cilliers (1996:52) ten opsigte van prediking in Suid-Afrika vandag. Deur die Anglikanisme, die Metodisme, die Pentakostalisme en die Charismatiese Beweging is 'n sterk stroom van die Arminiaanse verlossingsleer gevestig. Gereformeerde prediking word dus hiermee gekonfronteer en daarom is dit gepas om ten slotte die implikasies van die Arminianisme in Suid-Afrika vir gereformeerde prediking by wyse van enkele stellings aan te toon. 


\section{Die implikasies van die Arminianisme vir gereformeerde prediking}

Die Arminiaanse leer oor die erfsonde, die vrye wil van die mens, die predestinasie op grond van die vooruitgesiene geloof, die moontlikheid dat die genade van God weerstaan kan word en dat die gelowige weer uit die genade kan uitval, lyk op die oog af na 'n geringe aksentverskuiwing in die Calvinisme. Tog het die leer vir die prediking ingrypende implikasies. Hierop word in die volgende stellings gewys:

- Vanweë die Arminianisme se afskaling van die erfsonde en die gevolge daarvan word gewerk met 'n optimistiese antropologie. Dit lei noodwendig daartoe dat die vrye wil van die mens vooropstaan. Die mens het as gevolg van die genoegsame genade die inherente vermoe om God aan te neem of te verwerp. Daarenteen beklemtoon gereformeerde prediking die totale sondedoodsheid van die mens en sy algehele onvermoẻ om enigsins iets by te dra tot sy verlossing. Die sondaar kan God alleen deur die verligtende werking van die Heilige Gees ken.

- As gevolg van die Arminianisme se optimistiese antropologie word die vrymag van God, die genade en die offer van Christus gedevalueer. God as die uitsluitlike outeur van die verlossing word vervang deur 'n sinergistiese verlossingsbeskouing waarin God en die mens vennote word in die redding en vernuwing van die sondaar. Hierdie verlossingsleer lei tot 'n aktiewe bekeringsdrif waarin die mens opgeroep word om "sy hart vir die Here te gee". Juis hierdie verlossingsbeskouing was die oorsaak van die bekeringsaksies van die Metodisme wêreldwyd. Arminiaanse prediking roep die mens op tot bekering sodat hy daarmee God se affektiewe verlossingsgenade kan verdien. Gereformeerde prediking roep mense op tot 'n gelowige omhelsing of aanneming van die weldade van Christus op grond van God se vrye genade en sy ewige verkiesing wat rus in sy totale vrymag.

- Die Arminianisme leer dat God sy genade aan alle mense aanbied. Die mens wat die genade in Christus aanvaar, word gered en ontvang momenteel die vernuwende werking van die Heilige Gees. Hy kan egter uit hierdie genade uitval en daarom word hy voortdurend op 'n wettisistiese en moralistiese wyse opgeroep tot 'n vroom lewe. Wettisisme en moralisme is kenmerkend van die Arminiaanse leer en lewe. Die gereformeerde prediking beklemtoon die vrye genade van God in Christus wat vir alle mense genoegsaam is maar alleen geld is vir dié wat dit in die geloof toeëien. Die genade word nie net aangebied nie, maar op grond van God se uitverkiesing aan die uitverkorenes toegesê en hulle word deur die Gees gelei en deur die Woord opgeroep om die genade deur die geloof toe te eien. Die geloof is ook 'n gawe van die Heilige Gees. Gelowiges se lewe word 'n dankbaarheidslewe kragtens die wet wat in hulle 
harte geskrywe is, dit wil sê, volgens 'n nuwe gesindheid wat voortvloei uit 'n hart wat vernuwe is. Hierdie uitverkorenes kan nie weer uitval uit die genade van God nie, maar moet hulle op grond van dié sekerheid daagliks tot God bekeer deur teen die sondesmet te stry en 'n dankbaarheidslewe te lei.

- Weens die Arminianisme se bekeringsdrif en standpunt oor universele heiliging word die volharding van die heiliges en die heiligmaking verwater. Gereformeerde prediking roep gelowiges op om te groei in die geloof, te volhard in die werke van die geloof en vroom te lewe volgens dit wat hulle is, naamlik kinders van God.

- Die Aminiaanse beskouing bied die uitverkiesing aan as ' $n$ toegif op die mens se keuse vir God. Geloofsekerheid word hierin nie gewaarborg nie en laat die mens in voortdurende twyfel lewe. Hy twyfel of hy 'n kind van God is en vrees dat hy weer uit die genade kan uitval. Gereformeerde prediking beklemtoon ook wedergeboorte en bekering voluit maar as finale motivering vir die verlossing en vernuwing van die sondaar word die uitverkiesing op grond van God se vrye genade in Christus aanvaar. Die bekeerde besef dat sy bekering nie berus op eie meriete nie, maar op die genade van God. Daarin vind hy ook geloofsekerheid.

Hoewel Arminius by Calvyn wou aansluit, het sy leer en die logiese uitbouing daarvan deur sy volgelinge 'n drastiese verskuiwing weg van die Calvinisme teweeggebring. Hierdie verskuiwing word duidelik wanneer gereformeerde en Arminiaanse prediking vergelyk word. Ten diepste kom die drastiese verskil op die volgende neer: gereformeerde prediking roep op tot toeëiening van 'n toegesegde genade, terwyl Arminiaanse prediking oproep tot 'n keuse vir God op grond van die vrye wil van die mens. Gereformeerde prediking skryf die verlossing geheel en al aan God toe terwyl die Arminianisme van die mens die eerste tree in die verlossingsproses verwag. Hierdie belangrike verskil laat die paaie van gereformeerde en Arminiaanse prediking op alle ander gebiede wyd uiteen gaan.

\section{Bibliografie}

ALAND, K. 1986. A history of Christianity. Phaladelphia : Fortress

ANON. 1988 The five articles of the Remonstrants. (In Bettenson, $\mathbf{H}$ Documents of the Christian Church. Oxford : Oxford University Press. p. 268-269.)

ARMINIUS, J. 1956a. A declaration of the sentiments of Arminius. (In Nichols, J., ed. The writings of James Arminius. Translated from the Latin in three volumes. Volume I Grand Rapids : Baker Book House. p. 277-380.)

ARMINIUS, J 1956b. The apology or defence of James Arminius. (In Nichols, J, ed The writings of James Arminius. Translated from the Latin in three volumes Volume II Grand Rapids : Baker Book House. p 193-264.) 
ARMINIUS, J. 1956c. On the predestination of believers (In Nichols, J, ed. The writings of James Arminius. Translated from the Latin in three volumes. Volume II. Grand Rapids : Baker Book House. p. 99-102)

ARMINIUS, J. 1956d. On the predestination of the means to the end. (In Nichols, J., ed. The writings of James Arminius. Translated from the Latin in three volumes. Volume II. Grand Rapids : Baker Book House. p. 102-103.)

ARMINIUS, J. 1956e. A letter to Hippolytus a Collibus. (In Nichols, J., ed. The writings of James Arminius. Translated from the Latin in three volumes. Volume II. Grand Rapids : Baker Book House. p. 453-478.)

ARMINIUS, J. 1956f. An examination of a treatise, concerning the order and mode of predestination and the amptitude of divine grace by Rev. William Perkins, D.D. (In Nichols, J., ed. The writings of James Arminius. Translated from the Latin in three volumes. Volume III Grand Rapids : Baker Book House. p. 279-525.)

ARMINIUS, J. 1960. De predestinatie (In Bakhuizen van den Brink, J.N. red Documenta Reformatoria. Kampen : Kok. Deel I. p. 277-282.)

ARMINIUS, J. 1986a. Analysis of Romans IX. (In Nichols, J., ed. The works of James Arminius. Volume III Grand Rapids : Baker Book House p. 485-519.)

ARMINIUS, J. 1986b. Examination of the theses of Dr. F. Gomarus respecting predestination (In Nichols, J., ed The works of James Arminius. Volume III. Grand Rapids : Baker Book House. p. 526-658)

BANGS, C. 1971. Arminius. A study in the Dutch Reformation. New York : Abingdon Press.

BERKHOF, L. 1991. The history of Christian doctrines. Edinburgh : The Banner of Truth Trust

BETTENSON, H. 1988. Documents of the Christian church. Oxford : Oxford University Press

BOGAARDS, A H. 1997. Die Christologie van Hermann Friedrich Kohlbrugge (1803-1875) Potchefstroom : PU vir CHO (Th.D -proefskrif.)

BOLSTER, G.R 1952. Wesley's doctrine of justification. Evangelical Quarterly, 24(3):144155 , July.

CAIRNS, E.E. 1981 Christianity through the centuries. Grand Rapids : Zondervan

CALVYN, J. 1949a. Institutie of onderwijsing in de christelijke godsdienst. Volume 1. Delft : Meinema.

CALVYN, J 1949b. Institutie of onderwijsing in de christelijke godsdienst. Volume 2. Delft Meinema

CILLIERS, J 1996. Die uitwissing van God op die kansel. Onstellende bevindinge oor SuidAfrikaanse prediking Kaapstad : Lux Verbi.

COETZEE, C.F.C. 1986. Die werk van die Heilge Gees in die teologiese denke van Andrew Murray Potchefstroom : PU vir CHO.

CUNNINGHAM, W. 1969. Historical theology A review of the principal doctrinal discussions in the Christian church since the apostolic age. Volume 2. London: Banner of Truth Trust.

DEWAR, M W. 1974. The British delegation at the Synod of Dort - 1618-1619. Evangelical Quarterly, 46(2): 103-116, April.

DIE DORDTSE LEERREËLS. 1992 Leerreels soos vasgestel deur die Dordtse Nasionale Sinode. (In Gereformeerde Kerke in Suid-Afrika Die berymde Psalms, Belydenisskrifte en Liturgie. Potchefstroom : Calvyn Jubileum Boekefonds. p. 557-589.)

DIE HEIDELBERGSE KATEGISMUS 1992. Kategismus soos saamgestel deur Z. Ursinus en C. Olevianus ( $n$ Gereformeerde Kerke in Suid-Afrika. Die berymde Psalms, Belydenisskritte en Liturgie Potchefstroom : Calvyn Jubileum Boekefonds. p. 517-556.) 
DONALDSON, ME. 1994. Christianity in the period of English colonisation (In Hofmeyr, J.W. \& Pillay, G.J A history of Christianity in South Africa. Pretoria : HAUM Tertiary p. 36-92.)

HARNACK, A. 1897. Lehrbuch der Dogmengeschichte. Volume 3. Leipzig : Mohr.

HINCLIFF, P. 1968. The church in South Africa. London : SPCK.

HOENDERDAAL, G.J. 1975. The debate about Arminius outside the Netherlands (In Lunsnigh-Scheurleer, Th.H en Posthumus Meyjes, G.H.M., eds. Leiden University in the seventeenth century An exchange of learning. Leiden : Brill. p. 137-159.)

HOFMEYR, J.W. 1994. Christianity in the period of Dutch colonisation. (In Hofmeyr, J W. \& Pillay, G.J. A history of Christianity in South Africa. Volume 1. Pretoria : HAUM Tertiary. p. 8-32.)

JONKER, W.D. 1994. Bevrydende waarheid Die karakter van die gereformeerde belydenis Wellington : Hugenote Uitgewers.

KRUGER, B.R. 1957 Die ontstaan van die Gereformeerde Kerk in Suid-Afrika. Pretoria : V en R Drukkery

LEITH, J.H. 1982. Creeds of the churches. A reader in Christian doctrine from the Bible to the present. Atlanta : John Knox Press

LETHAM, R.W.A. 1988 Aminianism. (In Ferguson, S.B, ed New dictionary of theology Leicester : InterVarsity Press. p. 45-46)

McCULLOH, GO. 1962. The influence of Arminius in American theology. (In McCulloch, G.O., ed. Man's faith and freedom. The theological influence of Jacobus Arminius New York : Abingdon Press. p. 64-87.)

MURRAY, A. 1868. Het moderne ongeloof, dertien leerredenen Kaapstad : Hofmeijr.

NATIONALE SYNODE VAN DORDRECHT. 1620. Acta of Handelinge der Nationale Synode in den Naam onzes Heeren Jezus Christus, gehouden door outoriteit der Hoogmagende Heeren Staten-Generaal der Vereenigde Nederlanden te Dordrecht ten NGB jare 16]8 en 1619. Leiden : Donner.

Kyk NEDERLANDSE GELOOFSBELYDENIS. 1992 Geloofsbelydenis soos opgestel deur De Brès. (In Gereformeerde Kerke in Suid-Afrika, Die berymde Psalms, Belydenisskrifte en Liturgie. Potchefstroom : Calvyn Jubileum Boekefonds p 488-516)

NUTTALL, G.F. 1962. The influence of Arminianism in England (In McCulloh, G.O., ed. Man's faith and freedom. The theological influence of Jacobus Arminius. New York : Abingdon Press. p. 46-63.)

SCHULZE, L.F. 1988. Geloof deur die eeue. Pretoria : NG Kerkboekhandel

SHEDD, W.G.T. 1978. A history of Christian doctrine. Minneapolis : Klock \& Klock.

SLAATTE, H A. 1979. The Arminian arm of theology. The theologies of John Fletcher, first Methodist theologian, and his precursor, James Arminius Washington : University Press of America.

SMITH, D.H. 1992. A handbook of contemporary theology Wheaton : Bridge Point.

VAN GENDEREN, J. 1996. Orientatie in de dogmageschiedenis. Zoetermeer: Boekencentrum.

WALKER, W. 1992. A history of the Christian church. Edinburgh : Clark.

WESLEY, J. 1982. The Scripture way of salvation. (In Leith, JH. Creeds of the churches A leader in Christian doctrine from the Bible to the present. Atlanta : John Knox Press. p. 360-373.) 